\title{
ADALÉKOK A TERÜLETFEJLESZTÉSSEL KAPCSOLATOS FOGALMAK VITÁJÁHOZ
}

(Some Things to Add to the Debate on the Concepts Concerning Regional Development)

FARAGÓ LÁSZLÓ

Mind a mai napig nem alakult ki egységes fogalom- és szóhasználat a területi kutatásokban és gyakorlatban. A szakma számos terminus technicust használ, de nem egységesen. A területfejlesztés fogalomrendszerének, feladatainak, eszközeinek áttekintése nem önmagáért való akadémikus vita, hanem e kérdések tisztázása nélkül igencsak nehéz a hatékony területi munkamegosztás kialakítása, a hatáskörök, döntési kompetenciák elosztása stb. Az új „épitésügyi” és a területfejlesztési törvény előkészítésében nem kis nehézséget okoz, hogy még az alapfogalmak tekintetében sincs konszenzus. A zürzavaros helyzet tisztulását nehezíti, hogy a területi tervezés a 80-as évekre világszerte elbizonytalanodott és a szocialista világrend összeomlása a tervezésbe vetett hitet is megingatta. Ma nemcsak az egyes kormányok gyakorlata mutat nemzeti sajátosságokból fakadó eltéréseket, hanem a különböző iskolák, felfogások sokasága is tovább tarkítja, gazdagítja a képet. Az Erópai Unió bővülése, a strukturális alapok felhasználásának eddigi tapasztalatai is reformokat vetítenek elöre.

A hazai viták eredménytelensége, a gyakorlat sürgetỏ szükségletei miatt úgy tünik, hogy a területpolitikában és a területi tervezésben nem történik jelentös megújulás, hanem a korábbi gyakorlat kozmetikázott rehabilitációjának esélyei nönek, amit a 94-es politikai fordulat tovább bátorít. Ez esetben a kérdés az, hogy a meröben új társadalmi-gazdasági közegben az miként tud majd funkcionálni?

A következőkben három kérdéskörről fejtem ki álláspontomat. Az elsó csokorban a területfejlesztés belső rendszerét és a kapcsolódó tevékenységekhez való viszonyát tárgyalom. Második témakörként a régióval foglalkozom részletesebben, mert úgy érzem ez a legkevésbé tisztázott területi alapkategória. Végezetül a területfejlesztés ideológiai meghatározottságára keresem a választ. Ez utóbbi kísérletre, kérdésfelvetésre az elmúlt év választási tapasztalatai késztetnek. Minden politikai erö durrogtatott területpolitikai petárdákat, de többségüknek nem volt kikristályosodott ez irányú akarata. A szakma és a tudomány képviselöi pedig nem tudtak, vagy a politikától való idegenkedésük miatt nem akartak nyilatkozni e kérdésben. 


\section{Területfejlesztés}

A teriuleti fejlödés a gazdasági növekedésnél komplexebb, a területfejlesztésnél tágabb fogalom

A területi fejlődés az össztársadalmi tevékenység eredményeként megvalósuló folyamat. A területi fejlődés vagy a térszerkezet alakulása/torzulása a területiséggel ab ovo számoló és más célokat követő beavatkozások eredőjeként következik be, míg a területfejlesztés elsősorban a kormányzat és az önkormányzatok tudatos beavatkozását jelenti. A területi folyamatokra döntö mértékben nem a területpolitikai eszközök hatnak, hanem a piac, az egyének, a gazdálkodók, a kormányzat gazdasági döntései. Ha egy régió vagy település erőforrásait vagy annak hasznositását adott időben nem ismeri el a piac, akkor csak nagy ráfordítások árán ideig-óráig lehet hagyományos területpolitikai eszközökkel lassítani a kedvezőtlen hatásokat.

A területi fejlódést a helyi társadalom számára a helyi folyamatok szerves folytatásaként jelentkezỏ belsó strukturális változások jelentik. A strukturális változás megjelenhet a termelési tényezők változásában, az eröforrások jobb hasznositásában, az intézményi rendszer átalakulásában és a lakosság értékrendjének és attitủdjének változásában egyaránt. Az egyén, a helyi társadalom szempontjából a fejlödés a lehetoóségek bövülését jelenti. Az egyén egyre több „fajta” munkahely, lakóhely, iskola stb. közül választhat, illetve egy adott lehetỏséget a helyi társadalom egyre szélesebb rétege vehet igénybe. A helyi fejlődés társadalmi megitélésekor hasznositható a Pareto-féle törvény adaptációja. Oberle, Stowers és Darby $(1974,62$. o.) szerint , ,... a fejlődés olyan folyamatként határozható meg, amelynek során egy adott terület növekvő számú tagja hoz és hajt végre társadalmilag helyes döntéseket, amelyek valószínũ következménye emberek életlehetőségeinek növekedése anélkül, hogy mások életesélyeit csökkentenék.

\section{A területfejlesztés a térhasználat tudatos irányitása}

A területfejlesztést gyakran a területi politika - csúnyábban kifejezve a regionális politika - rokon fogalmaként használják, de véleményem szerint ezek közel sem egymás szinonimái.

Ez a tévedés évek, hónapok folyamán a törvénykezési szándékokban is testet öltött. Többen területpolitikai törvény meghozatalát tartják szükségesnek a területfejlesztési törvénnyel szemben. Nem azt állítom, hogy nem lehet magas szintú normát alkotni a területpolitikáról, hanem azt, hogy két különböző dologról van szó.

Amennyiben az egyéb jogszabályok hiányosságai és a területi folyamatok szükségessé teszik önálló törvény megalkotását ${ }^{1}$, amelyben létrehozzák a területfejlesztés intézményrendszerét, kialakítják a szükséges és hatékony munkamegosztást, rendezik a hatásköröket - pl. kinek kell elökészíteni, kikkel kell megvitatni és mely intézménynek jóváhagyni az országos szintủ területi politikát --, biztosítják az eszközöket és szabályozzák a felhaszná- 
lásukat az a területfejlesztési törvény. Az a norma - mely véleményem szerint nem feltétlen törvény kell, hogy legyen -, amelyik meghatározza az aktuális területi célokat, preferenciákat és az adott időszakban esedékes beavatkozásokat, a meglévő eszközök konkrétabb felhasználását, szól a területpolitikáról.

Nem értek azzal sem egyet, hogy a területfejlesztést a területpolitika végrehajtására degradálják. Annál inkább nem, mert ma már képtelenség megmondani, hogy hol kezdódik a végrehajtás és hol van vége a politikának. A kettő között nem szekvenciális kapcsolat van, hanem dinamikus kölcsönösség, mindkettö hat a másikra. A politika nem egy fix entitás, hanem olyan intenciók együttese, amely alkuk és tárgyalások során alakul. Maga a megvalósítás pedig a politika és cselekvés interakciójának a folyamata.

A területfejlesztés a térhasználat tudatos irányítását jelenti, így az irányítási rendszerekhez hasonlóan a) területpolitikai, b) szabályozási, c) szervezeti/intézményi és d) az eszközöket tartalmazó alrendszerekböl áll. Az alrendszerek konzisztenciája elengedhetetlen feltétele a rendszer hatékony müködésének.

a) A területi struktúrák tudatos alakítása során követett prioritások (célok) és az ezek eléréséhez használatos eszközők és intézmények meghatározását, egyeztetését nevezem területpolitikának. A fejlett országokban a területpolitika évtizedek óta a központi irányítás szerves része, az ágazati politikákkal egyenrangú eleme a kormányzati munkának. Korábban (nem csak) Magyarországon elsösorban kormányzati szintủ politikát jelentett, ma az önálló helyi és regionális érdekek elismerésével és a kormányzattól fưggetlen autonóm döntéshozó testületek megjelenésével létezik helyi és regionális szintủ területi politika is. A kormány területpolitikája a térbeli folyamatok irányítására, a területi problémák kezelésére vonatkozó magatartása, amit törvény-elökészitési, szabályozási, elosztási és fejlesztési tevékenységében érvényesít. A regionális területpolitika nálunk ma még nem általános, de már vannak kezdeményezések a Dél-Dunántúlon és az Alföldre is készíttetett programot a kormány. Ma reális a veszélye e szint államositásának, ami ellentmond az európai tendenciáknak.

A területpolitika jellegét meghatározó tartalom térben és időben változó. Általában igaz, hogy fellendülés időszakában a méltányossági-szociális szempontok kapnak nagyobb szerepet, míg recesszió vagy a válság éveiben hangsúlyosabbá kell válniuk a hatékonysági-gazdasági kérdéseknek. Ezért pl. Várnainak - véleményem szerint - csak az elsö esetre vonatkozóan van igaza, mikor a területpolitika szociális karakterét hangsúlyozza. Egyetértek vele abban, hogy a különbözö szintủ területpolitikák értéktartalma eltérö kell, hogy legyen, de nem osztom véleményét abban, miszerint a magasabb szintủ területpolitika ,... a leszakadók számára a szükséges szociális védőháló területileg differenciált alkalmazását, a szolidaritást." jelenti (Várnai G. 1994, 80. o.). Mint már említettem a területpolitika nem szükségszerúen és nem csak szociális indittatású, söt ma inkább gazdaságpolitikai karaktere lenne kívánatos. Emellett a fejlett régióknak is célszerü területpolitikával rendelkezniưk. Tendenciájában a területpolitika közelebb áll a gazdaságpolitikához, de mégsem tekintem a gazdaságpolitika részének, inkább csak egyik megjelenési formájának. 
Bármely szintủ területpolitika kialakításakor elöszőr a szándék megfogalmazására kerül sor, azaz hagyományosan - az esetek többségében - a cél- vagy prioritás rendszer, majd a megvalósitáshoz elengedhetetlen eszközrendszer és a lebonyolításért felelős intézmények meghatározására, amelyek ismeretében konkretizálni lehet a teendőket. Természetesen a szándékhoz rendelhetỏ eszközök is hatnak a célokra és számolnunk kell az intézményi korlátokkal is. Így a célok elsődlegessége nem abszolút.

A területi célok/prioritások meghatározása a legkritikusabb. Egy szúk csoport által meghatározott célok csak jól múködő demokráciákban jelenthetik a cselekvési programok alapját. Az eszközök megválasztásánál viszonylag nagy a szabadságfok. Azonos eredmény különböző utakon, más-más eszközök segítségével is elérhetö, de ezek hatékonysága és külső hatásai eltéróek lehetnek. A rosszul kiválasztott intézmények eleve meghiúsíthatják a célok teljesítését.

Egy praktikusabb, elsősorban rövid és középtávú taktikák megfogalmazásánál lehet eredményes megoldás, ha célként a meglévỏ helyzet meghaladását jelölik meg, ekkor az adottságok leltára és a fejlesztési alternatívák kiértékelése jelentösebb szerepet kap, mint egy erösen megkérdójelezhetö jövőkép kialakítása esetén.

b) Területi szabályozás mint az irányítás egyik eleme a múkődésre gyakorolt tudatos beavatkozások/hatások összessége. A szabályozási rendszer két irányban közvetít. Egyrészt a demokratikusan választott testületek által képviselt közakaratot kell közvetítenie az egyéni és csoport döntéshozatal irányába, másrészt a bekövetkező változásokat kell viszszajeleznie.

A jogrendszer adja a területi szabályozási alrendszer kemény magját, de az egyéb normák és közvetító mechanizmusok is fontos szerepet játszanak. Ma már nem jogszabályi erejủ, de fontos irányítási eszköz lehet pl. az országgyúlési határozat ${ }^{3}$, ami kelló befolyást gyakorolhat a folyamatokra. Puha elemei a rendszernek például azok a programok, irányelvek, amelyek befolyásolják a müködést, de nem részei a jogrendszernek, betartásuk nem szankcionálható (pl. pártprogramok, koalíciós megállapodás, ${ }^{4}$ válságkezelési programok).

c) A munkamegosztás következményeként a különbözö tevékenységek különböző szervezeti keretek között folynak. A funkciók és hatáskörök egymástól elkülönült egységeinek, kereteinek rendszere lényegében a szervezeti és intézményi rendszer. A szervezeti és intézményi rendszer a területi struktúrát követi, mind vertikálisan (ország, régió, megye, vonzáskörzet, település), mind horizontálisan (pl. településrendszer) jól tagolt.

Fontos a hatáskörök pontos és egyértelmủ elkülönítése. A területfejlesztés eddigi gyakorlata is mutatja, hogyha ez nem így van, akkor ebböl milyen bonyodalmak származhatnak. ${ }^{5}$ Ma ez a területfejlesztés egyik leggyengébb eleme.

A szervezetekkel kapcsolatban fontos megjegyezni, hogy azok nem passzív befogadók, nem egyszerủ végrehajtói a döntéseknek, hanem azok megvalósitására pozitív vagy negatív hatást gyakoroló tényezők. ${ }^{6}$ A szervezeti intézményi struktúra szakaszosan követi a bekövetkezó változásokat, így mindig viszonylagos lemaradásban van. 
d) A területi irányítási rendszer jellegét is nagyban meghatározza, hogy többségében milyen eszközöket alkalmaz és ki milyen szinten diszponál azok felett.

$\mathrm{Az}$ általános gazdaságpolitikai eszközöknek (monetáris eszközök, hitel- és kamatpolitika, nyíltpiaci múveletek, adópolitika, szociálpolitika, támogatási rendszer stb.) jelentős területi vonatkozásai vannak. Ha ezek meghatározásánál nem vizsgálják a területi kihatásokat, akkor annak negatív területi hatása is lehet, amely megkérdőjelezheti az eredeti szándékot. ${ }^{7}$

A területi tervezés a területfejlesztés legföbb, aktív eszköze. Több tényezö is indokolja az eszközök sorából való kiemelését. A tervezés eszköz, de a célok megfogalmazásában, alakitásában is fontos szerepe van, tehát a területpolitikára aktívan hat. A korábbi gyakorlat azért is hibás volt, mert a célok és az eszközök, valamint a célok és a megvalósulás folyamata kőzött nem volt iteratív kapcsolat. Az utópikus célok megkérdőjelezhetetlen dogmaként való kezelése korlátozta a lehetséges megoldásokat, modellben gondolkodva korlátként jelentkeztek. A tervezési folyamat során felszinre került tények nem tudtak hatni a célokra. A helyzetet csak súlyosbította, hogy a célok nem társadalmi konszenzus eredményeként születtek, hanem a társadalom nevében, téves ideológia alapján egy szük csoport alkotta őket. Az információk kizárólagos birtoklása, illetve fals információk nyilvánosságra hozatala tartotta fenn az utópikus célokat. Ezek bármilyen hatékony teljesitése csak rossz eredményre vezethetett.

Amikor egy tervet egy testület elfogad és az részben vagy egészében normává válik, akkor maga a terv közvetlenül is szabályoz, így az a szabályozó rendszer része. Tervlebontásos rendszerben, ahol a tervek végrehajtása kvázi kötelezö, a terv egyes területeken a legfóbb szabályozó lehet.

Az általános rendezési tervek végsỏ fázisában szabályozási terv készül, amely az önkormányzati testület által való elfogadása után direkt módon behatárolja a lehetséges fejlesztéseket. A területi koncepciók és tervek indirekt módon is hathatnak a folyamatokra. Erre jellemzỏ példa az 1971-ben elfogadott OTK. A megjelent dokumentum nem adott cselekvési programot, megvalósításának nem voltak eszközei, mégis nagy hatást gyakorolt a területi folyamatokra.

\section{Településfejlesztés}

Korábban - a helyi döntések szabadságfokát tekintve - a településfejlesztés is központi feladat volt. Ma az önkormányzati törvénynek köszönhetỏen a településfejlesztés fó céljait és feladatait a helyi társadalom akaratával összhangban az önkormányzatok szabadon határozzák meg. Tehát a településfejlesztés a helyi fejlesztési politikảt, a helyi fogantatású és finanszirozású tevékenységeket öleli fel, ami igen komplex, sokirányú tevékenység. Nem minden fejlesztési döntésnek van rendezési konzekvenciája.

A településfejlesztés - véleményem szerint - része a területfejlesztésnek, így az oly gyakran használatos „terület- és településfejlesztés" szókapcsolat számos szövegösszefüggésben tautológia. ${ }^{8} \mathrm{~A}$ területfejlesztés a tágabb kategória és magába foglalja a telepü- 
lésfejlesztést, mert a tér bármely pontján bekövetkezô változás közvetlenül megváltoztatja a térstruktúrát is.

E véleményemet elóször 1987-ben a Tér és Társadalom hasábjain adtam kőzre (Faragó L. 1987), mely nem nyert elfogadást még a szúkebb szakmában sem. Késóbb mint köztisztviseló a javaslatomból eredö konzekvenciákat sem a törvényhozásban, sem a kormányzati munkamegosztásban érvényesíteni nem tudtam. Azóta is várom érvrendszerem szakmai cáfolatát. Ennek hiányában is tudomásul kell vennem, hogy a szakma rangos képviselöi és a bưrokrácia egyaránt a terület- és településfejlesztés terminus technikust használja és külön kezeli a területfejlesztést és a településfejlesztést. Az esetek többségében - problémák, szóvegösszefüggés - kényszert éreznek a kettỏ explicit említésére.

Mi lehet ennek az oka? Valószínúen érvrendszerem bár logikusnak tủnt, mégis hibásnak bizonyult. Nem a gondolatmenetem volt megalapozatlan, hanem nem számoltam súlyuknak megfelelöen e résztudomány és a szakma fejlődéstörténetébỏl eredő kényszerhelyzetekkel, érdekcsoportokkal, a tehetetlenségi erővel. „Mellesleg” e törekvés ellen hatott az önkormányzatok megerósödése és e folyamat gyermekbetegségei.

A magyar területpolitika és területi tervezés követó jellege miatt nagyobb figyelemmel kellett volna lennem az európai gyakorlatra. A nemzetközi gyakorlat a magyartól eltérö, ott jellemzỏen a várostervezés és a regionális tervezés különül el. Az elsó tevékenység döntố részben a minél hatékonyabb fizikai környezet kialakítására törekszik, míg a másik középpontjában a gazdasági fejlödés és a természeti és társadalmi környezet közötti egvensúly áll. A kettő szétválásának alapvető oka a területpolitikai célokban és azok elérésének módjaiban van.

Mindebből következhet a területfejlesztés és a településfejlesztés vertikális területi struktúra metszetében történó megkülönböztetése. Több települést érintő térségi feladatok esetében területfejlesztésről, míg egyes telepủlések, kisebb egyưttélő telepủléscsoportok esetében településfejlesztésröl beszélhetünk. Ezt támasztja alá az az újra erósödő nézet, miszerint a területfejlesztés elsősorban a kormány nagyobb területegységekre vonatkozó beavatkozásait jelenti, továbbá a középszintek területfejlesztési hatáskörével kapcsolatos bizonytalanság, azok államosítására irányuló törekvések is.

Ez esetben azonban felhívom a figyelmet arra, hogy e felosztás alapja a területi tervezésen belül kialakult munkamegosztás, ami nem ok hanem következmény jellegủ. Az elkülönủlés inkább funkcionális, prakticista megosztást jelent, így e két tevékenység kiegészíti, kölcsönösen feltételezi egymást és az egyuttmüködés igénye eo ipso adódik.

A településhálózat-fejlesztés mint a telepúlésállomány rendszerének tudatos alakítása elsősorban kormányzati és regionális feladat. Az urbanizáció elsô szakaszának lezárulásával, a piaci viszonyok uralkodóvá válásával lényegesen veszitenek jelentőségůkbỏl az ez irányú beavatkozások. Minél fejlettebb egy ország és területileg minél kiegyenlítettebb a fejlettsége, annál kevésbé van szükség az állam telepúléshálózat-fejlesztési beavatkozásaira. A 90-es évtizedben a hálózatokban való gondolkodás erösödésével ủjra a terủletpolitika homiokterébe kerülhet a városhálózatok kérdése. 


\section{Területrendezés}

A település, a régió és az ország egész területén az érdekegyeztetések során kialakított területpolitikai céloknak megfelelő térbeli fizikai szerkezet kialakítása, megvalósitása a területrendezés. Tehát a „rendezés" a „fejlesztési” elhatározások egy konzekvencia csoportja, így e két tevékenység egyazon folyamat része, bár a területfejlesztési elhatározások a megvalósítás során sok irányban mennek tovább, amelyek közül csak egy a területrendezés. A megvalósítás - így többek között a területrendezés - során nyert tapasztalatok vissza kell, hogy hassanak a fejlesztési célkitüzésekre, de nem lenne szerencsés, ha a végrehajtás mozzanata ,önállósítaná" magát és egy elkülönült, mellérendelt tevékenységi kört jelentene önálló célrendszerrel. Ez utóbbi számos legitimációs, irányítási problémát vetne fel. Ebből a szempontból nézve a ,fejlesztési” tevékenységnek koordináló, integratív szerepe is van, amit tovább erösít a ,területi” aspektus.

A területfejlesztés korábban vázolt négyes tagozódásán belül a területrendezés az eszközök és a szabályozási elemek közé sorolható, önálló célmeghatározó, koncepcionális szerepe nincs. A területrendezés megvalósíthatósága érdekében gyakran jogszabályokat kell alkotni, mert korlátozhatja az állampolgárokat és egyéb tulajdonosokat jogaik gyakorlásában.

A rendezési terv a kívánatos állapot megvalósítását szolgáló eszköz, amelynek többek között feladata a többségi akarat érvényesítése és az ezzel ütköző szándékok korlátozása. A kormányzat rendezési tervet készittet a nemzeti területrendezési érdekek érvényesítése érdekében, valamint az országos, területi és helyi teruletfelhasználási szándékok közötti konfliktusok feloldására. A megyék területrendezési tevékenysége elsősorban a több települést érintő infrastruktúra megteremtésére és a kőrnyezetvédelem, -fejlesztés feladatainak ellátására irányul. A helyi önkormányzatok településfejlesztési céljaik megvalósitása és az egyéni érdekek megfelelő keretek között tartása érdekében rendezési tervben szabályozzák a természeti és müvi környezet alakítását.

A rendezési tervekkel az állampolgárok többsége mint korlátozó tényezővel találkozik, és sokan e funkcióját tartják a legfontosabbnak. Véleményem szerint lényegesebb feladata a fejlődés korlátainak megszüntetése, a fejlesztések fizikai környezetének biztosítása. Ez alapvető szemléleti kủlönbséget jelent. Tehát a rendezés viszonylagos önállósága elsősorban abban áll, hogy "lesi" a fejlesztés igényeit és azt minél hatékonyabban, a környezeti feltételeket is tiszteletben tartva próbálja kielégíteni, tehát végrehajt és kiszolgál. Ennek elfogadása természetesen csak azok számára lehetséges, akik nem hiszik, hogy a rendezési tervezésnek kell meghatároznia a fejlesztés ,játékszabályait" vagy az a letéteményese a fenntartható fejlödés elvének stb. A korábbi évek gyakorlata, mikor a rendezési tervezéssel foglalkozó müszaki végzettségü és beállítottságú emberek voltak kénytelenek pótolni a fejlesztési célokat, prioritásokat, az egy kényszerhelyzet szülte pótcselekvés volt.

Tehát a területfejlesztés és a területrendezés egymáshoz való viszonya nem teljesen ugyanaz, mint a fejlesztési és rendezési tervezésé. A fejlesztési és a rendezési tervezés tartalmában, módszereiben és a megvalósítás eszközeiben eltér, így a munkamegosztás 
következtében a gyakorlatban is elkülönülhetnek és természetesen külön dokumentumokban jelenhetnek meg, de lényeges a kettő igen szoros iteratív kapcsolata. Magyarországon de facto és de jure is elkülönült az elsösorban társadalmi-gazdasági típusú fejlesztési és a müszaki-fizikai rendezési tervezés, amely az intézmények közötti munkamegosztásban oly mértékben megcsontosodott, hogy a rendszer fájdalmas beavatkozások nélkül aligha megváltoztatható. A két tervezési tevékenység viszonylagos elkülönülését a feladat eltéró jellege is szükségessé teszi.

A fejlesztési tervezés innovatív formában, széles körủ részvételen kell, hogy alapuljon, amely során a problémamegoldást a tervezők gyakran tranzaktív módszerekkel is kereshetik. Az innovatív tervezés nyújt lehetőséget a meglévő struktúrák változtatására, mely megteremti a nemkívánatos trendek megváltozásának feltételeit és animálja az értékválasztást.

A rendezési tervezés allokatív tervezés, amely a meghatározott fejlesztési prioritások és a fennálló struktúra (szabályozás, intézmények stb.) keretei között keresi a megvalósitás leghatékonyabb/legméltányosabb fizikai kereteit. A korlátozottan rendelkezésre álló forrásokat (föld, telek, infrastruktúra stb.) osztja el az egymással versengö felhasználók, fejlesztési igények között. Tehát a rendezési tervezés a fejlesztési tervezésnél szükebb körủ tevékenység és a tervezők szerepe is más a tervezési folyamatban.

$$
\text { A régió }
$$

A magyarországi régiók kialakítása sokszori nekifutás után ma újra napirenden van, de a területi fogalmak közül a régió értelmezése, használata okozza talán a legtöbb zavart, e körül tapasztalható a legtöbb bizonytalanság még a szakmában is.

Richardson (1978) szerint a területi kutató számára rémálom a régió pontos meghatározásának az igénye és megkönnyebbül, amikor arra késztetik, hogy a közigazgatási határokhoz igazodjon, pláne, ha az adatok csak ahhoz állnak rendelkezésre. Hoover tréfás javaslatot tesz a definiálás megkerülésére: „... a régió olyan területet jelöl, amely vizsgálatára pénzt kap a kutató" $(1975,15$ o. o.

A régió kétségtelenül egy flexibilis kategória, de egy bizonyos, hogy a nemzeti és a települési szint között található. Az eltéró megközelítések, értelmezések forrása, hogy a régió „egy fogalom és konkrét realitás” egyszerre (Isard, W. 1956).

Sokan csak a valóság megismerésének egyik eszközeként, módszertani eszköznek tekintik és mint klasszifikációs egységet kezelik a régiókat, amelyek vizsgálati szempontból hasonló településekböl épülnek fel, vagy éppen eltérnek és ezért részei a nagyobb egységnek (pl, ország). Magyarországon a jelenlegi központi törekvések is mint statisztikai, tervezési egységet kívánják kezelni a következö években kialakítandó régiókat. ${ }^{9}$

A régióknak mint klasszifikációs egységeknek legalább öt alaptípusát lehet megkülönböztetni:

- földrajzi régió, természeti tájak; 
- közigazgatási/politikai régió (pl. saját törvényhozói hatáskörrel Belgiumban, Olaszországban, Spanyolországban; önkormányzati hatáskörrel Franciaországban, Hollandiában, Portugáliában);

- homogén régió: vizsgálati szempontból (kultúra, gazdasági szerkezet, jövedelmi szint stb.) egynemü/hasonló terưletegység;

- funkcionális régió: hasonló feladatot, tevékenységet ellátó terület, ahol a belső területegységek funkcionális kapcsolatban állnak egymással (pl. nehézipari körzetek);

- program régiók: tervezési egységek, illetve valamilyen program által érintett terület. Kedvezö, ha van egy olyan szervezet, amelynek döntési kompetenciája, felelössége az adott területre vonatkozik. Ha ilyen nincs, akkor a program idejére célszerü azt létrehozni.

A ,regionális” kifejezést mint absztrakciót sokan (pl. Horváth Gy., Várnai G.) speciális tartalmától megfosztva a „területi” szinonimájaként használják és így regionális politikáról, regionális tudományról stb. beszélnek. Több új intézmény megalakulásakor is e - véleményem szerint rossz, de ma már nem megváltoztatandó - gyakorlatot követte elnevezésében (Regionális Kutatások Központja, MTA Regionális Tudományos Bizottsága).

Az angol munkák magyar fordításában sokszor a „regional”-t „szép magyarsággal” regionálisnak fordítják. Ezért a területi gazdaságtan regionális gazdaságtan, a területi tudomány regionális tudomány néven került be a köztudatba. A „regionális” fogalomnak a „területi” szinonimájaként való használata mindmáig nem okozott zavart, mert régiók hiányában az ilyen szintü kérdések elkülönült megjelölésére nem volt igény. E helyzet reményeim szerint hamarosan megváltozik. A zavar elkerülésére, a szükséges diszjunkció megtételére a régiópolitika, a régiótervezés stb. fogalmak használata kínálkozik, amelyek ma még kétségtelenül idegenül hangzanak.

Mint realitás, mint konkrét területi egység a régió lehet bármely több települést magába foglaló terület, amely valamilyen közös jellemzövel, érdekkel bír, vagy amellyel társítható valamilyen probléma vagy feladat. Nem csupán alanya, hanem aktív aktora csak akkor lehet a folyamatoknak, ha létezik regionális identitás, ha e szinten sajátos folyamatok termelődnek újjá, azaz sajátos tartalma és jelentése van a régiónak. Ez pedig ma már nem kétséges. Az egyes régiók társadalmi, gazdasági karaktere eltérő, ebböl következően problémáik és lehetőségeik is különbözőek, továbbá mások az igényeik a társadalmi és fizikai környezet alakításával szemben is. Vannak problémák (munkanélküliség, társadalmi-gazdasági elmaradottság, depresszió), amelyek értelmezése és kezelése sem lehetséges helyi szinten. Ennek alapján szokták a probléma-körzeteket tipizálni: elmaradott, rurális, válság körzetek/régiók.

Mint absztarkciónak és mint konkrét realitásnak is sajátos jelentéssel kellene bírnia az egyéb térkategóriákkal (település, ország stb.) szemben. Ha a több településre kiterjedő területi szinten valamely kérdés sajátos minöséget kap vagy bizonyos érdekek azon a szinten jelennek meg és válnak artikulálhatóvá, akkor beszélhetünk csak valós régióról, ennek hiányában csak üres klasszifikációs vagy adminisztratív egységröl lehet szó. 
A régiók a 60-as, 70-es években nem kaptak kellő figyelmet a területi és politológiai kutatásokban, viszont a 80-as évektől a „Régiók Európája” gondolat megszületésétől mindenütt (gazdaságfejlesztés, tervezés stb.) a gondolkodás középpontjába kerültek.

A szubszidiaritás ${ }^{10}$ mint az európai feladatmegosztás egyik vezérelve feltételezi a föderatív államot vagy legalább a régiók létét. Magyarországon többek között ez is szükségessé teszi a regionalizációt. Az európai integráció során ki kell alakítani a régiókat és intézményeiket. Ebben az esetben több mint célszerü figyelembe vennünk az európai ajánlásokat. A Regionalizáció Közösségi Chartájának 1. cikkelye alapján a régió olyan terület:

„1) amely földrajzi szempontból nyilvánvaló egységet képez, avagy olyan területek homogén komplexuma, melyek zárt szerkezetet alkotnak, és amelynek lakosságát bizonyos közös elemek jellemzik, akik az ebböl származó tulajdonságokat szeretnék megőrizni és továbbfejleszteni azért, hogy elősegítsék a kulturális, társadalmi és gazdasági fejlődést.

2) A lakosság „közös elemein” a nyelvet, kultúrát, történelmi tradíciót és a gazdaságot és közlekedést érintő közös jellemzői értendők. De nem feltétlenül szükséges, hogy ezen elemek egyidejüleg érvényesek legyenek.

3) Ezen egységeknek a különbözö államokban más-más elnevezése, jogi politikai helyzete lehet (autonóm közösségek, tartományok, nemzetiségek stb.), ami a jelen chartában lefektetett megfontolásokból nem zárja ki öket."

A regionalizmus a „középszint” kérdéskörével foglalkozik és általában a regionális szintü önigazgatás és önkormányzat létrehozására irányul. Szükségszerúen gyengíti a központi állam hatalmát, de nem a dezintegráció irányába hat, így például Európában is az egységesítési mozgalmakat erósíti. A transznacionális regionalizmus is a közeledést és nem az elhatárolódást erósíti. Fontos eszköze és eredménye a decentralizáció.

A valós régiók léte és múködőképessége szempontjából alapvető a regionális identitás, amely abban a kultúrában gyökerezik, amelyet a régió szereplői önmaguk alakítanak. A területi függés pozitív tudata, vállalása függ a területi egységen belüli és a külső kapcsolatoktól, valamint a társadalom egészéhez fúződő viszonytól. A területi-kulturális identitás történelmi kategória és nem egy változatlan örökség vagy a tradíciók egyszerü halmaza. Olyan belsỏ dinamikus folyamat, amelyet a társadalom önmaga állandóan alakít, mely belső tudatosan és önként vállalt átalakulások során fejlödik, elfogad külső hozzájárulásokat, asszimilálja vagy ha szükséges transzformálja azokat. Ez az azonosságtudat egyre inkább feltétele az egyének, a csoportok és a nemzetek fejlödésének. A területikulturális identitás a kollektív akarat és cselekvés alapja. 


\section{A területfejlesztés politikai karaktere}

Ma már szakmai közhely, hogy Magyarországon 1985-ig nem beszélhettünk explicit területpolitikáról. A fentröl lefelé építkező ágazati irányítási rendszerbe nem volt beilleszthető a területi megközelítés. A rendszerváltást követöen joggal merülhet fel a kérdés, hogy milyen hatással lesz a hosszú távú elkötelezettséget igénylö területfejlesztésre a négyévenkénti kormányváltás, amely nem ritkán más ideológiai/politikai megközelítést is jelent.

1990-ben a nép-nemzeti konzervativizmus ,fiatalos” lendülettel kanyarodott vissza a romantikus hagyományokhoz. Ami a múltból megmaradt vagy feleleveníthető azt változtatások nélkül mumifikálni akarták. Úgy gondolták, hogy korrigálni kell a ,,szocialista intermezzo" által elkövetett hibákat, ki kell köszörülni a történelmi folyamatosságon esett csorbát. A konzervatív ideológia kezdeti lépései nem a decentralizáció, hanem a nemzetépítés irányába mutattak, ami jelentős idöbeni késést jelent Nyugat-Európához képest.

A 90-es évek eleje nem hozott áttörést a területpolitikában. Az Antall-Boross-kormány területpolitikája nem került írásban lefektetésre, azt nem fogadta el a kormány és nem hirdette meg, de döntésein és gyakorlatán nyomon követhető volt. Föbb jellemzöi:

- szelektív területeken avatkozott be;

- centralizált döntési rendszert müködtetett;

- társadalmi, méltányossági szempontokat preferált a hatékonysági kritériumok rovására;

- defenzív volt, utólagos korrekciós szerepet játszott;

- indokolatlan mértékben koncentrált Északkelet-Magyarországra.

Tehát az önkormányzatok kvázi hatalmi ágként való megjelenésén kívül a társadalmigazdasági élet egyéb területeivel ellentétben e négy év nemhogy forradalmi változásokat, de semmi újat nem hozott az 1985-1989-es szakaszhoz képest. "' Rövid megtorpanások után a 80-as évek második felében megkezdett területpolitikát igyekeztek megvalósítani.

A szocialisták 1994 elején jól mérték fel a helyzetet, miszerint a magyar társadalomban sokkal erősebb az egyenlőség, az egyenlösdi iránti vágy, mint a nyugatiakban. Sokan inkább elfogadják az alávetettséget, a szükségletek minimális, de biztos kielégítését, mint az olyan szabadságot, amivel sokan nem tudnak mit kezdeni. Választási területfejlesztési ígéreteik is ezt az elemi, de illuzórikus igényt szolgálták. Fél év elteltével „intézményi kozmetikázások"-tól eltekintve kardinális változásokat nem lehet a területi politikában kitapintani. Az elmúlt négy évhez képest a megye területfejlesztési vonatkozásokban is megerősítést nyert, de hogy ténylegesen az új konstrukció hogyan tud majd müködni az a most megalkotandó jogszabályokon múlik. Erősödik annak veszélye, hogy a területfejlesztés a korábbi struktúrákhoz és múködési mechanizmusokhoz kanyarodik vissza.

Már az elsö félév elteltével látni lehetett, hogy a Horn-kabinet területi prioritásai megegyeznek az MDF vezette koalícióéval. Jelenleg területpolitikai szempontból úgy tủnik, hogy ők is „két megyében szeretnék megnyerni a választásokat”, amibe elődeik bele is buktak. A területfejlesztés szempontjából nem jó ómen, hogy a területpolitika helye és 
szerepe a központi politikában, intézményeinek kialakítása, eszközeinek felhasználása elsősorban politikai alkuk eredménye és szakmai szempontok újra nehezen törnek utat maguknak.

Mi lehet annak az oka, hogy e téren megint nincs lényeges változás, illetve ami van az a „,szocialista” gyakorlathoz való visszakanyarodás? Szükségszerü-e hogy így legyen? Természetesen nem tudnék és nem is szándékom mély politikai elemzésbe bocsátkozni. Mivel a szakma számos képviselöje nem kerülheti el, hogy a gyakorlati kormányzati munkához a szakterülete oldaláról kapcsolódjon, jó lenne tisztázni számos - korábban az egypártrendszerben fel sem merülö - ideológiai, politikai kérdéskört.

A kővetkezö sorokban leírt néhány gondolat nem kimerítő válasz a felvetódó kérdésekre, de reményeim szerint sokakat indít továbbgondolkozásra.

\section{Az ellentmondás harmóniája}

Általános alapelv, hogy a kormányok és önkormányzatok területpolitikájának - mint minden más részpolitikának - általános politikai aktivitásukkal egyezö irányúnak kell lennie, és a területi intézmény- és eszközrendszer sem lehet alapvetỏen más típusú. Ugyanakkor e trivialitás számos ellentmodáson keresztül tendenciájában lehet csak igaz.

Egyrészt a területpolitika a gyakorlatban kihasználhatja az önmozgásában rejlö lehetőséget és korrigálhatja a makropolitika nemkívánatos területi hatásait. Így lehetséges például, hogy egy szélsőségesen liberális gazdaságpolitika éppen a területpolitika szociális feladatait erősíti.

Másrészt, ha a központi és a helyi vagy regionális kormányzat politikai jellege eltérő a központi kormányzatétól, ${ }^{12}$ akkor a helyi önkormányzatok konvertálhatják a központi értékeket és szándékot, amire a kormányok „természetes" reakciója a centralizációs törekvés.

Harmadrészt, ami a legnehezebbé teszi a különbözö ideológiákhoz tartozó területpolitika meghatározását, hogy a különbözö politikai eszmerendszerek a modern politikai gyakorlatban összekeverednek.

A területi folyamatokhoz igazodás szükségességét jelzi, hogy a kormányzatban egymást váltó pártok a választási retorikát követöen nagyon hasonló területi politikát folytatnak. A konzervatívok a kezdeti szigoritások után folytatják a szociáldemokraták jóléti, méltányossági politikáját, a szociáldemokraták pedig egyre inkább a liberális gazdaságpolitikától várják a jóléti társadalom bukásának elkerülését.

Tovább nehezíti a területfejlesztés politikai karakterének meghatározását, hogy nem dólt el az az alapvetö kérdés, hogy mi a területpolitika és a nemzeti gazdaságpolitika viszonya. Sokan a szerkezetátalakítást területpolitikai kérdésként kezelik, ugyanakkor Magyarországon erös a hatalomhoz közelebb álló, hagyományos közgazdász tábor véleménye, miszerint a területi fejlödés a nemzeti szintủ versenyképesség alakulásának függvénye. Ha a makrogazdaság növekszik, akkor nö a depressziós területek revitalizálásának 
az esélye, ha stagnál vagy hanyatlik, akkor a területi beavatkozások is csak szociális programokkal enyhíthetik a tüneteket. Természetesen mint a területi megközelítés mellett elkötelezett kutató ilyen szimplifikált módon az utóbbi nézettel nem érthetek egyet. A regionális és helyi gazdaságfejlesztés nemcsak regionális és helyi gondokat orvosolhat, hanem nagyban hozzájảrulhat a nemzeti szintü kibontakozáshoz is.

\section{A konzervatív területpolitika jellemzői}

A konzervatív területpolitikában egyaránt megtalálhatjuk a romantikus konzervativizmus, a szociálkonzervativizmus, a neo-konzervativizmus és a kereszténydemokratizmus hatását. Közös bennük, hogy mindegyik elismeri a területi politika és a központi beavatkozás szuikségességét, kialakításukban és megvalósításukban a hagyományos emberi közösségekre és korporációkra építenek. A hangsúlyt az általános gazdaságpolitikai eszközökre teszik, amit szelektív térségi támogatásokkal egészítenek ki. A feladatokat korlátozott számú intézményre decentralizálva hajtják végre. A területi tervezés allokatív formája az általánosan használatos.

A romantikus konzervatív ideológiai gyökerek leginkább a nép-nemzeti konzervatív erök területpolitikájában ismerhetők fel. Politikájuk általában vidékpárti és benne a nemzeti múlt, a természeti örökség megőrzése fontos prioritás. Ipari szerkezetátalakítási programjaik nem érintik az alapvető struktúrákat és a mezógazdaságnak az ország és a vidék fejlesztésében döntő szerepet szánnak.

A szociálkonzervatív területpolitika erősen alárendelt az általános antiliberális politikának.

Az amerikai újkonzervativizmus kőzelebb áll a liberális értékekhez, mint európai testvérei. Területpolitikájuk szerencsésen ötvözi a nagyváros-ellenességet, a nemzeti öntudat erősítését és más amerikai konzervatív elemeket a szabadverseny mítoszával, az allam terjeszkedésének visszaszorításával.

A Thatcher-kormány szabadpiaci konzervativizmusával összecsengett területpolitikája. Megszüntette a regionális támogatások java részét. Az állami ipar privatizálása, az innovatív kisvállalkozások és a csúcstechnológiát alkalmazó vállalatok támogatása egyértelmủen a fejlett magterületek további fejlődését segítette, újraerősítette az ország korábbi megosztottságát és ismét Dél-Britannia lett a nyertes. A területfejlesztésre fordított támogatások összegét nagyságrendileg meghaladták az állam hadiipari megrendelései, melyeknek fele ugyancsak a délkeleti régióra koncentrálódott. $\mathrm{Ez}$ a területi különbségek és az ebből eredő feszültségek élezỏdését eredményezte.

Az európai kereszténydemokrácia elfogadja a leszakadó területek központi forrásokból való felzárkóztatásának szükségességét, a szerkezetátalakításból eredó szociális problémák kezelését stb. Ennek érdekében inkább a korlátozott piac elvét követi és e téren közel áll a szociáldemokráciához és a szociálliberalizmushoz. 


\section{A liberális területpolitika jellemzöi}

A liberális területpolitika a liberális alapértékeken nyugszik, így a szabad individuumok és képviseleteik önkéntes társulásaiból építkezik. A gazdaság- és területpolitika kulcselemének a decentralizációt tartja. A neoliberális makroökonómiára támaszkodó politikai erők mérsékelt területi beavatkozást tartanak szükségesnek. Jelentősebb területi különbségeket is tolerálhatónak vélnek. A területpolitikát prakticista elvek alakítják. A szerkezetátalakítás a piachoz igazodás politikája, mely a komparatív előnyök újraértékelését jelenti az új nemzetközi munkamegosztás, a verseny és jövedelemtermelési feltételek alapján. Az egymással versenyző és hatékonysági szempontokat figyelembe véve kooperáló, vállalkozóbarát önkormányzatokat tartják helyesnek.

\section{A szocialista-szociáldemokrata területpolitika jellemzöi}

Elfogàdott alapállása az intervencionizmus. Kiterjedt állami támogatásokkal kívánjảk a piac szereplöit döntéseikben befolyásolni. Neokeynesi gazdaságpolitikai alapokon nagy központi programokat finanszíroznak és hajtanak végre. Szerkezetátalakításkor a társadalmi szempontokat, a munkaerő érdekeit elönyben részesítik, ezért a hanyatló ipari térségek támogatása a döntỏ elem. Preferálják a társadalmi tulajdonformákat, ösztönzik az önkormányzati vállalkozásokat. Lehetövé teszik, hogy az önkormányzatok beavatkozzanak a gazdaságba. A piacot nem a legföbb szabályozó erőnek, hanem olyan gazdasági térnek tekintik, amely terepe a gazdasági regenerálási programoknak.

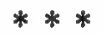

A fent említett területpolitikák tiszta formában a legritkábban fordulnak elö. A területpolitikára és a területi tervezésre mind kormányzati mind regionális és helyi szinteken elsősorban az objektív területi folyamatok hatnak és nem a hatalom politikai karaktere. $\mathrm{Az}$ ideológiai platform nem annyira a területpolitika tartalmát, mint inkább stílusát és eszközeit határozza meg. Sokkal erősebbek a nemzeti sajátosságok - így eltér a brit, a francia vagy a német gyakorlat - , mint a hatalmon levó pártok ideológiai azonosságaiból következö hasonlóság.

A területi folyamatok periódushossza nagyobb, mint a kormányzati ciklusoké. Számos területi beavatkozást is e hosszabb távú folyamatokhoz kell igazítani, amiböl az következik, hogy politikai kurzusváltásoktól fuiggetleníteni kell a területfejlesztési programokat.

Továbbá a területpolitika jellegére nagyobb hatással van a kormányzó párt(ok) politikai, ideológiai gyökereinél a gazdaság állapota, a nemzetközi piaci helyzet és a történelmileg kialakult és megörökölt területi struktúra. ${ }^{13}$

A második világháború utáni gazdasági fejlődés önmagában is a térbeli kiegyenlítést szolgálta, és a fellendülés is több eszközt adott egy méltányosabb, szociálisan érzéke- 
nyebb területfejlesztés számára. Ezzel szemben a 70-es évektöl divergens folyamatok zajlanak. Ha tetszik, ha nem, tényként kell kezelnünk, hogy a mindannyiunk hosszú távú érdekeit szolgáló szerkezetátalakulás területi polarizációt eredményez, a területi egyenlótlenség fokozódik. Az új ipari fejlődés az erổs központi támogatás ellenére sem a válságövezetekben bontakozik $\mathrm{ki}$, hanem ott, ahol a gazdaság diverzifikált, a $\mathrm{K}+\mathrm{F}$ tevékenység fejlett, a termelő és pénzügyi szolgáltatások kiterjedtek stb. E folyamatokból adódó feladatok azok, amelyek elsósorban meghatározóak. A gazdaság által behatárolt keretek között hangsúlyeltolódás általában a célok tekintetében és az alkalmazott eszközök jellegében lehet. İgy eltérések mutatkoznak a területi irányitás jellegében, egyes elemeiben, például a területi tervezés formájában és stílusában. Tehát ab ovo nem a konzervatív, a szocialista és a liberális területfejlesztés tér el egymástól, hanem sokkal inkább az intervencionalista és a piaci erőkre támaszkodó, decentralizáltan operáló liberális.

\section{Jegyzetek}

I Jelenleg nálunk ez a helyzet.

2 A helyi (terület)politika az önkormányzati politikánál tágabb fogalom. Magába foglal(hat)ja a társadalmi szervezetek településre vonatkozó politikáját is. A településfejlesztésben való participáció nemcsak az ơnkormányzaton keresztül valósulhat meg, hanem közvetlenul is.

3 Pl. az Országgyülés 12/1980-1985. számú határozata a terulet- és telepulésfejlesztés hosszú távú feladatairól.

4 Az 1994-es választásokra készülve tőbb párt készített terủletpolitikai programot, így a kormányzó MSZP és SZDSZ is.

5 Például 1990 és 1994 között e hiányosságokból számos hatásköri vita volt a BM és KTM között.

6 Például a Belügyminisztérium nem az elmaradott területek és a válságkörzetek, hanem a támogatandó telepullések lehatárolásában és elfogadtatásában érdekelt, így szakmai érvek és az európai gyakorlat ellenére is ezért harcol.

7 Például egy adórendszerbeli változás jelentős jövedelem-átcsoportosítást jelenthet a különbőző telepưléstípusok között.

8 Természetesen nem a telepulésfejlesztés onnálló entitásának megkérdőjelezéséről van szó, hanem e szókapcsolat szükségszerủ használatáról. Abból a tényböl, hogy a nagyobb területi egység a kisebbekből épül fel nem következik, hogy a települések fejlesztésének mechanikus összessége lenne a területfejlesztés. A társadalmi-gazdasági fejlôdés számos kérdése csak területi szinten értelmezhetŏ és kezelhető.

9

„Régió: több megye területére kiterjedő tervezési, illetve statisztikai egység.” A terulletfejlesztésről és rendezésröl szóló tv. tervezete. KTM 1994. november 3., 5. o.

10 Ebben az esetben a területi szintek kőzötti (vertikális) kompetencia-megosztás elve. A szubszidaritás elvének az Európai Közösség dokumentumaiban való megjelenésének az elemzését lásd $W$. Hummer és $S$. Bohr munkájában (1994).

11 A kormányzati struktúrában, az intézményrendszerben bekővetkező átalakítások lényegi, tartalmi változásokat nem eredményeztek. Az önkormányzatok a megszerzett pozícióik megerösítésével, védelmével, a müködés, fenntartás napi gondjaival voltak elfoglalva a teruletfejlesztésben játszott szerepükre kevesebb gondot forditottak.

12 Az önkormányzati és a parlamenti választások közötti fél éves időszak miatt gyakran eltér a helyi és a központi kormányzat politikai karaktere. 1990-ben a konzervativ kormány mellett a városok tỏbbségében liberális vezetés volt, ami tovább élezte a vidéket szavakban képviselö konzervativizmus és a modernizációt felvállaló liberálisok ellentétét. 
13 Például Szabolcs-Szatmár-Bereg megye peremhelyzetén alapvetóen nem a kőzponti teruletfejlesztési támogatások fognak segíteni. Az ország gazdaságának élénkulése, Ukrajna konszolidációja külon beavatkozások nélkül, rơvid távon is tơbb eredményt hoz, mint a megye hosszabb távú kiemelt "segélyezése".

\section{Irodalom}

A területfejlesztésról és rendezésrỏl szóló tơrvénytervezet. KTM, Budapest, 1994. november 3.

Faragó L. (1987) A területfejlesztés fogalmáról. Tér és Társadalom, 1. 1-15 o.

Hoover, E. M. (1975) An Introduction to Regional Economics. Alfred A. Knopf. New York.

Hummer, W.-S. Bohr (1994) A régiók szerepe a jövô Európájában. Baranya Megyei Kozgyúlés Hivatala, Pécs.

Isard, W. (1956) Regional science, the concept of regions and the regional structure. Papers and Proceedings of the Regional Science Association, 2. 13-29. o.

Oberle, W. H.-Stowers, K. R.-Darby, J. P. (1974) A Definition of Development. Journal of Community Development Society, Vol. 5, No. 1, 61-71. o.

Várnai G. (1994) Várospolitika és regionális politika, Falu-Város-Régió, 3-4. 80-82. o.

\section{SOME THINGS TO ADD TO THE DEBATE ON THE CONCEPTS CONCERNING REGIONAL DEVELOPMENT}

\section{LÁSZLÓ FARAGÓ}

The currently running law- and decree making process (and also the communication among researchers dealing with regional issues) is made more difficult by the fact that the concepts in connection with regional planning are not clear. For this reason in the first part of his work the author makes a suggestion for the interpretation and the system of these concepts. He interprets regional development as a category that comprehends, organises the conscious control of the spatial processes and divides it into four subcategories: the regional political, the management, the organisational/institutional one and the one that contains the means.

In the second topic he deals with the interpretation of the concept of the region, because in his opinion this is the least clarified regional basic category and the their formation is on schedule in Hungary these days. This chapter, besides raising theoretical issues, contains suggestions of the EU, as well.

Finally the author is searching the answer to the ideological determination of regional development. This latter attempt can be defined as an innovative one, since the election experiences of last year show that in the programmes of the majority of the parties the regional policy was the least established one. Also, the representatives of the field and science - probably due to their aversion from politics- have not published in this topic. 
Faragó László: Adalékok a területfejlesztéssel kapcsolatos fogalmak vitájához.

Tér és Társadalom, 8. 1994. 3-4. 23-39. p.

Comparing the regional policies in accordance with the conservative, liberal and social democratic values and the actual governmental behaviours the author gets to the conclusion that regional development, both in governmental and local levels, is mainly affected by objective regional processes, not by the political character of the power. The ideological platform defines the style and the means of the regional policy rather than its content. In international comparison the national features are much stronger than the similarity deriving from the ideological identities of the parties in power.

Translated by Zoltán Raffay

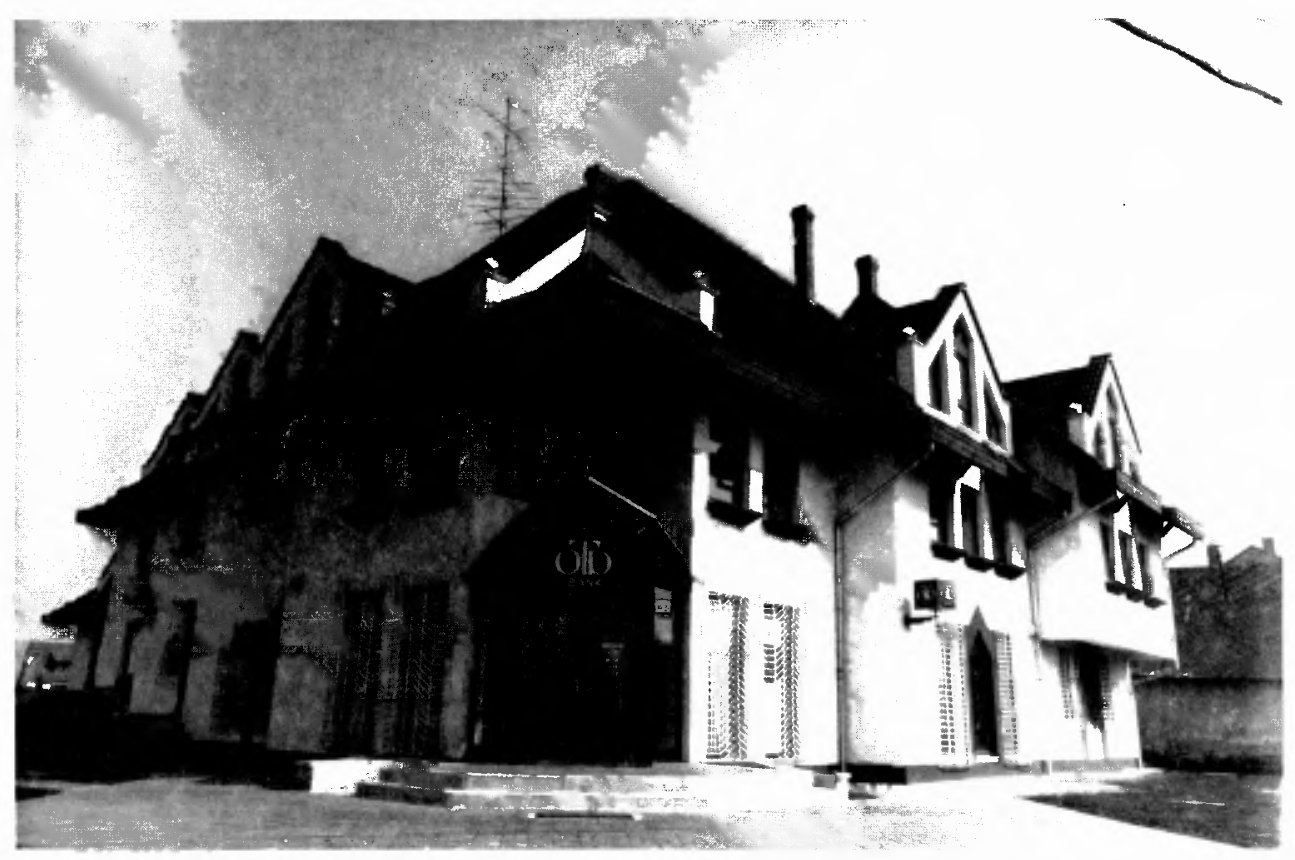

Korszerü OTP Bank nyillt Bükön (MTI FOTÓ - Czika László) 
Tér és Társadalom 8. évf. 1994/3-4. 40. p.

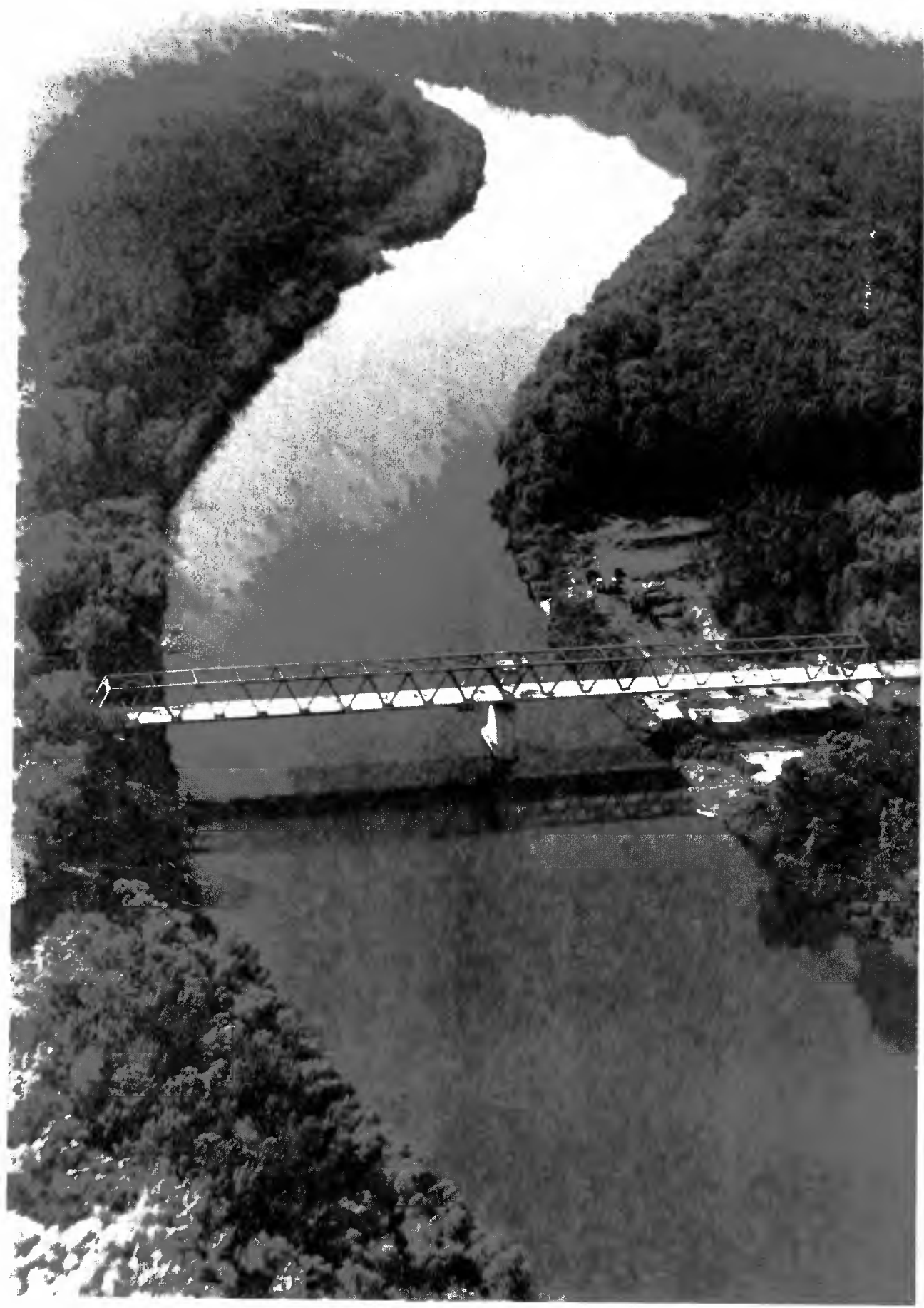

Új hid a Tiszán (MTI FOTÓ - Kozma István) 